\title{
Mean Reversion in Real Exchange Rates in Seventy LDCs: An Empirical Investigation
}

\author{
Augustine C. Arize \\ Regents' Professor \\ College of Business and Technology, Texas A\&M University - Commerce \\ Commerce, Texas 75429, U.S.A.
}

Tel: 903-886-5691, Fax: 903-886-5693 E-mail: Chuck_Arize@tamu-commerce.edu

Received: March 1, 2011

Accepted: April 25, 2011

doi:10.5539/ijef.v3n5p24

The authors would like to thankAllan Headley, Ed Manton, Don English, and Harold Langford for helpful comments on earlier drafts. Special thanks to Kathleen Smith, Patcharaporn Sanglua and Sabrina Zaman for excellent research assistance.

\begin{abstract}
So far, comprehensive investigations of the behavior of real exchange rates in LDCs are scarce in the literature. As several LDCs policymakers have been implementing a purchasing power parity (PPP)-oriented exchange rate policy while others have continually intervened in the foreign exchange rate market, there is need to ascertain whether or not there is empirical support for mean reversion of real exchange rates or long-run PPP in LDCs. This study investigates the long-run PPP hypothesis in seventy LDCs. Our data are real effective exchange rates (REER) for the period 1980:1 through 2009:10 (i.e., 358 observations). Our results reveal evidence of mean reversion that is significantly stronger compared to that obtained by using linear tests alone, strengthening the support for PPP. The results find strong evidence in favor of both linear and nonlinear mean reversions, with the nonlinear mean reversion dominating beyond the 2005 sample period.
\end{abstract}

Keywords: Unit Root, Nonlinearity, Real Effective Exchange Rate

JEL: F31, F41

1. Introduction

In international economics, the stationarity of real exchange rates or mean reversion is critical for the empirical verification of the long-run purchasing power parity (PPP). The theory of PPPstatesin its absolute version that in the absence of international arbitrage,the nominal exchange rate, expressed as unitsof the domestic currency per unit of the foreign currency, should be equal to the price ratio between the home and foreign country.(Note 1)Because of the importance of PPP as the cornerstone of many exchange rate determination models, as an equilibrium exchange rate relation by itself and as reference in policy decisions, testing PPP has continued to attract the attention of many researchers, but with mixed results (Officer, 1976; Isard, 1987; Hasan, 2004; 2006, Narayan, 2005).

The PPP is important to policymakers in less-developing countries (LDCs) for several reasons. First, it may be used to forecast exchange rates. Second, it provides a reference point for judging the movements of exchange rate, especially whether a currency is over - or undervalued. Knowledge of the degree of exchange rate misalignment can be helpful in the management of inflation and the implementation of monetary policy. Third, it is used for international comparison of national income levels and trade flows. Finally, as far as is known, policymakers in LDCs have been implementing PPP-oriented exchange rate policy reforms by implicitly assuming that the real exchange rate data are stationary and that relative prices are the relevant determinants of the correct levels of exchange rates. As Dornbusch and Krugman (1976: 540) point out, "Under the skin of any international economist lies a deep-seated belief in some variant of the purchasing power parity theory of the exchange rate" (Note 2), consequently, the validity of PPP is important to policymakers. This is so because macroeconomic policies based on estimates of PPP exchange rates may be flawed if the real exchange rate is non-stationary. (Note 3) Research on PPP has therefore focused on the credibility of the nonstationary findings by some authors and on why deviations from PPP exist.

As researchers failed to obtain convincing evidence in support of stationarity of REER by employing the Augmented Dickey-Fuller (ADF) tests, they switched to using the DF-GLS test developed by Elliot, Rothenberg and Stock (1996). Although both tests are based on linear models and utilize the same null hypothesis of 
nonstationarity (no adjustment towards PPP) against the alternative hypothesis of linear stationarity(adjustment towards PPP), the DF-GLS test is said to have higher power and is more likely to reject the null hypothesis of nonstationarity. It is further argued to be better able to distinguish between a unit root and a root that is large but less than one (i.e., the near unit root case). Nevertheless, the empirical evidence from employing these two linear specifications has been inconclusive. Taylor (2001) attributes failure to reject the null of nonstationarity to the current linearity methods used in empirical testing and points out that time aggregationand the presence of nonlinearity in the data generating process tend to reduce the power of the unit root tests.

With this uncertainty concerning the empirical validity of PPP, Kapetanois, Shin and Snell (2003), [hereafter KSS (2003)] have introduced a new test that accounts for non-linearity in the mean-reversion process of a time series variable.A possible criticism of the KSS test is the maintained symmetric nature of the deviations from equilibrium. Should this indeed not be the case, it would be necessary to adopt tests for asymmetric nonlinearities.

Nonlinearity in the adjustment toward long-run PPP could arise: first, because of observed transaction costs in international arbitrage, such as transportation costs and changes in trade barriers (Rogoff, 1996), (Note 4)which could create a price gapamong similar goods traded in spatially separated markets (see Sarno and Taylor, 2002; Taylor and Taylor, 2004);second, as Taylor (2004) notes, due to intervention operations by central banks in the foreign exchange market in an attempt to manage inflation and influence trade flows; and third, as Kilian and Taylor (2003) point out, because market participants have different beliefs concerning the equilibrium level of the nominal exchange rate, especially in developing economies where information barriers and government restrictions often give rise to heterogeneity of opinions in the foreign exchange market [see Taylor and Taylor, 2004:148,for a more detailed discussion].

Several studies have applied the new testby KSS (2003) to determine whether the bilateral real exchange rates are nonlinear but stationary. Some examples of this group are Taylor, Peel and Sarno, 2001; Kapetanios, Shin, and Snell, 2003; Chortareas and Kapetanios, 2004; Sarno, Taylor, and Chowdhury, 2004; Lothian and Taylor (2005), Bahmani-Oskooee and Gelan (2006) and Bahmani-OsKooee, Kutan and Zhou (2008). A finding that real exchange rates follow nonlinear stationary processes will suggest the PPP is valid and that real exchange rates adjust to its long-run equilibrium in a nonlinear fashion. A limitation of studies that have relied on bilateral real exchange rates is that it is possible for the observed nonlinearity to be dominated by the numeraire country. Suppose that the Japanese yen is used as the base currency and that it is continuously biased or moving away from the PPP, then in all bilateral rates we would get a replication of such a behavior over time.

Besides the bilateral exchange rates issue, the focus of some of these studies is on industrial countries. For LDCs, the empirical evidence on PPP is relatively small, and the possibility of nonlinear mean reversion has received little attention. In addition to being scant, the econometric evidence on mean reversion rests on samples that exclude post-2005 period. The world wide escalating increases in commodity prices, especially energy and the steepest rise in food inflation, which started in September of 2005, had substantial and somewhat gradual effects on LDCs. These effects, eventually have led to, for example, continuing increases in import fuel bills, falling export revenues and commodity prices; falling exchange rate reserves; rising poverty rates and slower growth rates, to mention but a few. [See Commission of the European Communities (2009) report titled Supporting Developing countries in Coping with the Crisis and World Bank $(1996 ; 2005)$ for a more complete explanation.]. Such developments in energy and food prices may have resulted in nonlinearity given the massive importance of these factors to LDCs. An IMF (2008:9)study notes that "In sum, the comparison of the current commodity price boom with the earliest ones suggests that the current boom has been more broad-based and longer lasting and that prices have risen by more than usual." It seems prudent to determine the extent to which the conclusions in Bahmani-Oskooee, Kutan and Zhou (2008) [henceforth BOKZ (2008)] may be confirmed for these LDCs by using our longer and more recent data.To summarize, linear and nonlinear mean reversions of REER in LDCS have not been studied in greater detail using longer estimation periods and the nonlinear unit root tests. The present study adds to the emerging basic literature on PPP hypothesis in LDCs.

The purpose of this study is to empirically investigate the validity of PPP in seventy LDCs over the monthly period 1980:1 through 2009:10. Monthly data are preferable because they are the lowest level of time aggregation available for price indices. The data consist of thirteen Asian, twenty African, seventeen European and twenty Latin American LDCs.

There are several value added of this study concerning PPP in LDCs. The first is the number of LDCs studied, and the sample periods are particularly extensive. In addition, they enable us to speak on the question of sample-selection biashypothesis (SBH). (Note 5) With the exception of one or two studies, the existing studies of PPP mentioned earlier are problematic because they focus on countries that are fairly homogeneous with regard to 
the degree of economic development and there is therefore little room for Harold-Balassa-Samuelson (HBS) effects to operate. This is not the case with our data set. The second value added is to provide information on whether the HBS effect is appropriate for LDCs. As is well known but often ignored in empirical research, reversion to parity in real exchange rates in LDCs is more often observed when linear estimators that allow for a linear trend in the data are employed. Lip service is often paid to what constitutes reversion to PPP (see Yazgan, 2003). As pointed out by BOKZ (2008), a significant linear or nonlinear trend in unit root testing may be ascribed a Harold-Balassa-Samuelson (HBS) interpretation to a mean-reverting real exchange rate around a trend. The HBSeffect is one of the most popular propositions against PPP, and it occurs because of differential rates of productivity growth in traded and non-trade goods sector of a country relative to that of her major trading partners (Taylor, 2002). We shed some light on this important issue by examining reversion to a trend in our data.

The third value added is that we use real effective exchange rates (REER) instead of the bilateral real exchange rate data employed by some of the existing studies. The use of the real effective exchange rate enables us to avoid issues concerning the possibility of dominance of numeraire currency. This is so because REER is an average (weighted) of bilateral exchangerates and averaging is more likely to eliminate the effects of the base country's experience on the index; thus, it allows for a test of PPP on multiple trading partners. Actually, its use as a measure of a country's external competitiveness assumes that the long-run PPP holds between a country and its trading partners.

The fourth value added is that our empirical analysis uses two linear unit root tests, namely the ADF and DF-GLS, which have the null hypothesis of nonstationarity (or no adjustment towards PPP) and the alternative of linear stationarity (or adjustment towards PPP). In addition to the linear tests, we employ two new nonlinear unit root tests, namely the KSS and the Sollis, which have the null hypothesis of a unit root or nonstationarity (i.e., no adjustment towards PPP) and the alternative of nonlinear stationarity (nonlinear adjustment towards PPP). The linear and nonlinear tests are applied to the monthly real effective exchange rate (REER). From a statistical standpoint, we know that it is inappropriate to rely on the performance of a single test for inference purposes (Gunst and Mason, 1980: 167-206). Therefore, an appealing aspect of our study is that there is no "onesize-fits-all" approach because a different model may be required to capture the individual nuances of different countries' data sets (McMillian, 2009).

The final value added is that we provide the first evidence for PPP in this literature for the following countries-the Bahamas, Bahrain, Congo, Greece, Iran, Israel, Nigeria and Saudi Arabia - using both linear and nonlinear estimators.Further, we provide evidence on transition countries of the former Soviet Union as well as the small open European (SOE) economies. These countries have largely been ignored in empirical studies.All in all, the use of a wide range of countries, longer and more recent data, including testing methodologies is an advance for LDCs literature on PPP.

This study differs from BOKZ (2008) at least in at least three respects. First, it considers a longer and more recent sample period. Our data are monthly REERs from 1980:1 through 2009:10, culminating in 358 observations, in some cases. Our data are taken from one source: the International Monetary Fund (IMF)'s International Financial Statistics (IFS) CD-ROM (2010), including Supplement on Prices published by IMF. The study by Bahmani-Oskooee and Gelan (2006) created data for REER for quarterly period 1971:1 through 2004:3, (Note 6) and therefore includes data from the pre- and post-Bretton-Woods era.

On the other hand, BOKZ (2008) employed REER data from several sources, namely IFS online, the OECD Economic Indicators and the Information Notice System of the IMF. Their data are largely from 1980:1 through 2005:8, and therefore focus on the generalized floating exchange era. The data used by BOKZ (2008) contain over twelve countries whose observations started in 1990s; over fourteen countries whose data started at least in 1985; and except for Cyprus, Malta and Turkey, the data for all European LDCs started in the 1990s.

Second,unlike BOKZ (2008),we usetwo linear tests, namely, the ADF and the DF-GLS tests. For testing nonlinearity in the series, we use the KSS (2003) test which assumes that the nature of the deviations from equilibrium is symmetric. Since exchange rates can respond in a different fashion to over-valuation and under-valuation, we alsotest for possible asymmetric adjustment in REER by using Sollis (2009) and Pascalau (2007).

Third, unlike BOKZ (2008), we incorporate eight LDCs - the Bahamas, Bahrain, Congo, Greece, Iran, Israel, Nigeria and Saudi Arabia - which, to our knowledge, have not been studied in the published PPP literature for LDCs.

The format of the paper is as follows: Section 2 provides a brief review and outline of the KSS test for nonlinearity. Section 3examines the empirical results. Section 4 presents the summary and conclusions reached by this study. 


\section{Methodology}

As noted earlier, the common practice when testing the time series properties of a variable has been to use the ADF and DF-GLS procedures in which the null is nonstationarity and the alternative hypothesis is stationarity. Recently, KSS (2003) expanded the standard ADF test by keeping the null hypothesis as nonstationarity in a time series variable against the alternative of a nonlinear but globally stationarity process. They demonstrate that the new test could be based on the following exponential smooth transition autoregressive (ESTAR) specification:

$$
\mathrm{y}_{\mathrm{t}}=\mathrm{y}_{\mathrm{t}-1}+\gamma \mathrm{y}_{\mathrm{t}-1}\left[1-\exp \left(-\theta \mathrm{y}_{\mathrm{t}-1}^{2}\right)\right]+\varepsilon_{\mathrm{t}}, \mathrm{t}=1, \ldots \ldots, \mathrm{T}
$$

where, $\varepsilon_{\mathrm{t}} \sim$ i. i. d. $\left(0, \sigma^{2}\right)$. Equivalently, the above equation can be rewritten as follows,

$$
\mathrm{y}_{\mathrm{t}}=\left\{1+\gamma\left[1-\exp \left(-\theta \mathrm{y}_{\mathrm{t}-1}^{2}\right)\right]\right\} \mathrm{y}_{\mathrm{t}-1}+\varepsilon_{\mathrm{t}}
$$

KSS (2003) transformed equation (2) as follows,

$$
\Delta y_{t}=\gamma y_{t-1}\left[1-\exp \left(-\theta y_{t-1}^{2}\right)\right]+\varepsilon_{t}, \theta \geq 0
$$

where $\mathrm{y}_{\mathrm{t}}$ is the de-meaned or detrended series of interest, $\varepsilon_{t}$, is an i.i.d. error with zero mean and constant variance, and $\left[1-\exp \left(-\theta y_{t-1}^{2}\right)\right]$ is the exponential transition function adopted in the test to present the nonlinear adjustment. The null hypothesis of a unit root in $y_{t}$ (i.e., $\Delta y_{t}=\varepsilon_{t}$ ) implies that $\theta=0$, so that the term $\left[1-\exp \left(-\theta y_{t-1}^{2}\right)\right]$ is 0 . If $\theta$ is positive, it effectively determines the speed of mean reversion.

The KSS test hence directly focuses on the parameter by testing the null hypothesis of nonstationarity $\mathrm{H}_{0}: \quad \theta=0$ against the alternative hypothesis of nonlinear mean-reversion, , $\mathrm{H}_{1}: \theta>0$. Because $\theta$ in Equation (1) is not identified under the null, it is not feasible to directly test the null hypothesis. KSS (2003) thus reparameterize equation (3) by computing a first-order Taylor series approximation to specification (3) to obtain the auxiliary regression specified by equation (4):

$$
\Delta y_{t}=\delta y_{t-1}^{3}+\text { error }
$$

If the errors in equation (4) are serially correlated, an auxiliary regression with

$$
\Delta y_{t}=\sum_{j-1}^{\rho} \rho \Delta y_{t-j}+\delta y_{t-1}^{3}+\text { error }
$$

$p$ augmentationsis obtained where the lagged values of the regressand in equation (5) are included to eliminate serially correlated errors from the estimated model. The null hypothesis for equation (4) or (5) is $\mathrm{H}_{0}: \delta=0$, and the alternative hypothesis is H1: $\delta<0$.The asymptotic critical values to be used in the KSS test are given as the $t_{\mathrm{NL}}$ statistics in KSS (2003). They show that the conventional t-values for testing nonlinearity have non-standard asymptotic distributions under the unit root, I (1), null; hence, they obtained their critical values through stochastic simulations. The lags $p$ for our tests use $\mathrm{Ng}$ and Perron (1995) approach and themaximum number of $p$ was set to 24 .

Following BOKZ (2008), we estimate the $t_{\mathrm{NL}}$ statistics with both equations (4) and (5) and refer to them as $t_{\mathrm{NL} 11}$ and $t_{\mathrm{NL} 12}$, respectively, for de-meaned data, and $t_{\mathrm{NL} 21}$ and $t_{\mathrm{NL22}}$, respectively, for detrended data. The de-meaned or detrended data are obtained by first regressing each series on a constant or on both a constant and time trend, respectively, and then saving the residuals. Since the standard ADF (DFGLS) test statistics are also estimated, it is

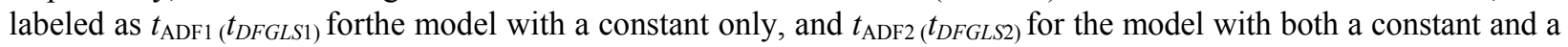
time trend. The rejection of the null by the KSS test with the de-meaned data or by the ADF (DFGLS) testthat includesonly a constant indicates reversion in REER to a constant mean, supporting PPP. If there is no evidence of reversion to a constant mean, but we are able to reject the null by the KSS test with detrended data or by the ADF (DFGLS) test which includes a constant and trend that would be an indication of linear or nonlinear in REER to a trend supporting HBS effect.

\section{Empirical Results}

The data in Table 1 present summary statistics for REER data for two general periods, 1980:1 through 2005:8 and 2005:9 through 2009:10. For each of the seventy countries, we provide the coefficient of variation (cv) and the Jarque-Bera statistics for two sub-periods. In addition, we report cvfor REER, nominal exchange rate (NEER) and relative price (RP) for the whole sample period.

\section{[Table 1 about here]}

Four key points are highlighted by the results. First, in almost all but a few cases, the cv of the first sub-period $(1980: 1-2005: 8)$ is larger than that of the second sub-period (2005:9 - 2009:10). Also, in almost every case, the Jarque-Bera statistic is significant at the conventional level. This is not the case with those reported for the second sub-sample period. 
Second, the summary statistics for REER for the second period suggest fairly moderate but significant evidence of exchange rate pass-through as prices adjust in several countries in response to economic reforms. For instance, the Jarque-Bera is not significant in thirty-eight (forty-three) of the seventy countries at the 5 (one) percent level. As noted earlier, several of the developing countries have experienced real shocks, such as droughts, oil and terms of trade shocks and political uncertainty. The literature suggests that such problems may have destabilizing effects on the PPP relation.

Third, another characteristics feature we observed is that when we compare the cv for REER of each country with the cv of its nominal exchange rate (NEER) and price-level (RP) components over the full-sample period, we observe that in a majority of the cases, the former is smaller and hence consistent with PPP. Specifically, in fifty-one of the seventycases, the coefficient of variation for REER is the smallest of the three. Of the fifty-one cases, Latin America has the highest, with seventeen; Africa has fourteen; Europe has thirteen; and Asia has seven. This is a rough and ready test of PPP.Further, that the values of the cv for the REERs are generally similar across the 1980:1 - 2005: 8 subperiod and the 1980:1 - 2009:10 period suggests that the variation of REER has been tolerably stable over time and hence leads one to conjecture that PPP may be favored by our data.

Fourth, in thirty-nine cases, the cv of nominal exchange rate is larger than that of the relative price. The thirty-nine cases are a mixture of thirteen, eleven, ten and five for Africa, Latin, Asia and Europe, respectively. These results indicate that nominal exchange rates are, in general, far more volatile than relative prices. In addition, in four cases -- Cameroon, Cote d'Ivoire, Togo and St Vincent -- variations in the nominal exchange rate and relative price are equal. Therefore, our empirical evidence corroborates previous findings supportive of high nominal exchange rate volatility in LDCs, such as Hausman et al. (2006) mentioned earlier. Nevertheless, it is worth noting that the cv of relative price is larger than that of the nominal exchange rate in twenty-seven cases, with Europe having the highest number of cases, that is, twelve; Latin America has eight; Africa has four; and Asia has three.

\section{[Tables $2-5$ about here]}

The empirical results of implementing ADF, DF-GLSand KSS tests are reported in Table 2 for thirteenAsian countries. Those for twentyAfrican countries, twenty Latin American countries, and thirteen European countries are reported in Tables 3 through 5, respectively. The sample periods studied for each country are given in Tables 2 through 5. Concerning the statistics, we have reported eight statistics for each country. Starting with the linear-type tests, the conventional ADF and DF-GLStests, whichincludeonly a constant, are denoted by $t_{\mathrm{ADF} 1}$, and $t_{\mathrm{DFGLS1}}$. In the case of the KSS test, for the de-meaned data employing equations (2) and (3), we report two test statistics. For equation (2) where there is no augmentation, it is denoted as $t_{\mathrm{NL} 11}$. For equation (3) with augmentation terms, it is denoted as $t_{\mathrm{NL} 12}$. The analogous statistic with a trend in the ADF is $t_{\mathrm{ADF} 2}$ for the DF-GLS test, it is $t_{\mathrm{DFGLS} 2}$, and for theKSS test, it is denoted as $t_{\mathrm{NL} 21}$ when there is no augmentationand $t_{\mathrm{NL22}}$ when there is augmentation.

Looking at Tables 2 through 5 and focusing on the first four tests, which are $t_{\mathrm{ADF} 1}, t_{\mathrm{DFGLS} 1}, t_{\mathrm{NL} 11}$ and $t_{\mathrm{NL} 12}$, the null of nonstationarity in REER is rejected by $t_{\mathrm{ADF} 1}$ at the 10 percent level of significance in fifteen countries. They are Singapore, Cote d' Ivoire, Equatorial Guinea, Zambia, Chile, Costa Rica, Dominican Republic, Grenada, Nicaragua, Paraguay, St. Lucia, St. Vincent and Grens, Greece, Iceland and New Zealand. This shows that the REER of these countries reverts to a constant mean linearly as per ADF tests. Clearly, according to the ADF test, these results confirm that the REER of these countries reverts to a constant mean in a linear fashion. As evident from the results for the DFGLS test, we have a total of five more countries -- St. Kitts and Nevis, Tobago \& Trinidad, Bulgaria, Cyprus and Moldova -- where the null of nonstationarity in REER is rejected by $t_{\mathrm{DFGLS}}$ but not by $\mathrm{t}_{\mathrm{ADF} 1}$.

Turning to the nonlinear test results, we gather that an additional twenty-five countries are rejected by $t_{\mathrm{NL} 11}$ and $t_{\mathrm{NL} 12}$, but not by $t_{\mathrm{DFGLS} 1}$ and $t_{\mathrm{ADF} 1}$, which points out the fact that a nonlinear mean reversion exists for these countries. Thus, for these countries -China, Israel, Samoa, the Solomon Islands, Burundi, Cameroon, Central African Republic, Congo, Lesotho, Malawi, Nigeria, Sierra Leone, Togo, Uganda, Bolivia, Guyana, Uruguay, Venezuela, Armenia, Croatia, the Czech Republic, Hungary, Malta, Norway and Poland -- the null hypothesis of nonstationarity of REER can be rejected at the 10 percent level in favor of the alternative hypothesis of nonlinear stationarity.

To piece together the outcome of the first four tests taken together, we note that our results are supportive of PPP by at least one of the four statistics in a total of forty-five countries out of seventy countries (64.28\%). It might be revealing to isolate how these tests (taken together) performed in each continent: the forty-five countries are a mixture of five (Asia), thirteen (Africa), fourteen (Latin America) and thirteen (Europe), respectively. These results also indicate that sample-selection bias hypothesis (SBH) does not seem to be important anymore as far as LDCs are concerned.

An important issue relates to the performance of each individual teststatistic in each country. For example, given our seventy countries, the $t_{\mathrm{ADF} 1}, t_{\mathrm{DFGLS} 1}, t_{\mathrm{NL} 11}$ and $t_{\mathrm{NL} 12}$ reject the null of nonstationarity in fifteen, nine, thirty-five and 
twenty-eight cases, respectively. Other appealing aspects of our results are that (1) the nonlinear unit root test results provide enough statistical evidence in support of nonlinear mean-reverting behavior in thirty-nine of the seventy countries; (2) KSS tests validate PPP in more countries than the standard ADF test (no matter which statistics are considered); (3) the number of cases in which the nonlinear tests (40 cases) reject the null of nonstationaritycompared with the linear tests ( 20 cases) is by a factor of two; and (4) based on our findings, the behavior of REER in Africa, Latin America and several transition countries (i.e., former Soviet Union - related economies as well as Central and Eastern Europe, for example, Bulgaria, Croatia and the Czech Republic) appear toexperiencemuch more nonlinear reversion to a constant mean than linear adjustment. Our empirical evidence corroborates previous findings supportive of the nonlinear adjustment hypothesis in transition as well as small open European economies. In sum, it can be argued that our study provides further evidence for the conclusion in Taylor and Taylor (2004:154-155) concerning the PPP debate that there may be a significant mean reversion of real exchange rates, while there may be factors causing the equilibrium real exchange rate to shift over time.

Now focusing on the ADF test results of Bahmani-Oskooee, Kutan and Zhou (2008) our results are consistent in forty-seven cases but they are inconsistent in eleven cases. Of the eleven cases, we obtain rejection of the null of nonstationarity in eight cases (Cote d'Ivoire, Equatorial Guinea, the Dominican Republic, Grenada, Nicaragua, Paraguay, St. Lucia and St. Vincent and Grens), but they did not, and in three cases (Pakistan, Samoa, Morocco) they reject the null of nonstationarity, but we failed to reject it. For the KSS tests, our results are consistent in thirty-one cases. However, they are inconsistent in twenty-seven cases. Of the twenty-seven cases, we found mean reversion in twenty-one cases (China, Samoa, the Solomon Islands, Burundi, Cameroon, Central African Republic, Cote d'Ivoire, Lesotho, Malawi, Uganda, Bolivia, the Dominican Republic, Grenada, Guyana, St. Lucia, Uruguay, Venezuela, Cyprus, the Czech Republic, Hungary and Malta) in which their KSS test results suggest that the series are nonstationary. In six cases (Pakistan, Morocco, Chile, Moldova, Poland and the Slovak Republic) they found evidence of mean reversion using the KSS method, but our data failed to confirm their finding.

\section{Nonlinear and asymmetric Reversion}

Based on the KSS test results, we have provided evidence that real exchange rate reversion to equilibrium could vary nonlinearly over time. However, the KSS tests assume that real exchange rates behave in a symmetrical fashion to both positive and negative shocks. Recent studies (e.g., Sollis, Leybourne and Newbold, 2002) have shown that factors influencing nonlinear behavior may also lead to asymmetric mean reverting process. For instance, asymmetry may occur in the point to which positive and negative deviations revert to the mean or in the speed of reversion between positive and negative deviations from equilibrium. To examine the possibility of asymmetric exponential STAR (ESTAR), we used the test suggested by Sollis (2009). For testing for logistic STAR (LSTAR), we utilize tests suggested by Pascalau (2007). From the test results, we gather that nonlinearity and stationarity are strongly supported and that asymmetric-ESTAR is favored in twenty-two countries -- Malaysia, Solomon Islands, Burundi, Cote d' Ivoire, Equatorial Guinea, Chile, Colombia, Costa Rica, Dominican Republic, Grenada, Guyana, St. Kitts and Nevis, St. Lucia, St. Vincent and Grens, Armenia, Australia, Bulgaria, Cyprus, Greece, New Zealand, Norway and Russia.On the other hand, we found that asymmetric-LSTAR nonlinearity is favored in few countries -Lesotho, Sierra Leone, Uganda, Zambia and Bolivia. It is worth noting that both nonlinearity and symmetric (instead of asymmetric) deviations appear to characterize the real exchange rate adjustments in nineteen countries (China, Israel, Samoa, Singapore, Cameroon, Central African Republic, Congo, Malawi, Nigeria, Togo, Paraguay, Uruguay, Venezuela, Croatia, Czech Republic, Hungary, Iceland, Malta and Poland). All in all, there is evidence that in majority of cases real exchange rates deviations appear to be generally nonlinear although stationary with some displaying symmetric as others display asymmetric mean reversion to PPP equilibrium.

\section{Comparison of Results}

One may wonder whether our results are consistent with those of BOKZ (2008). Our empirical evidence corroborates some of their findings. However, there are differences. For example, we find that PPP is supported in 64 percent of our sample, whereas it is 35 percent in their study. Second, we found support for the PPP in twenty-four cases in which they found no evidence of mean reversion. The countries are China, the Solomon Islands, Burundi, Cameroon, Central African Republic, Cote d'Ivoire, Equatorial Guinea, Lesotho, Malawi, Sierra Leone, Uganda, Bolivia, Dominican Republic, Grenada, Guyana, Nicaragua, St Lucia, Trinidad and Tobago, Uruguay, Venezuela, Cyprus, the Czech Republic, Malta and Poland. Third, in three countries - Pakistan, Morocco and the Slovak Republic-- they found support for the PPP hypothesis, whereas we found no support.

There are three reasons why our results would differ from theirs. First, the monthly periods we consider are different. Second, our results in Table 1 point to a shift in the data associated with a moderate exchange rate pass-through as prices adjust in various economies, leading to less incidence of linear mean reversion. Also, possible heterogeneity 
in the data resulting from continuing intervention in the foreign exchange market by the monetary authorities in some LDCs might have introduced more nonlinearity in the real effective exchange rate, hence more incidence of nonlinear mean reversion. All in all, our results support, at least in spirit, the findings of their studies and reinforce their conclusion that the PPP holds in a statistical sense in most LDCs. Third, unlike BOKZ (2008) and others, we have applied tests that examine whether the deviations from equilibrium are asymmetric. Our results showthat mean reversion behaviors can also be nonlinear and take the form of the ESTAR-type as well as the LSTAR-type, though more countries tend to display the ESTAR-type mean reversion to equilibrium than the LSTAR-type.

\section{HBS-type effects}

Having provided some evidence supporting the PPP, we can make the following observations regarding the HBS-type effects. For this, we rely on the last four statistics in Tables 2 through 5 ; that is, $t_{\mathrm{ADF} 2}, t_{\mathrm{DFGLS} 2}, t_{\mathrm{NL} 21}$ and $t_{\mathrm{NL22}}$. Our focus is on the twenty-five countries where the PPP is unconfirmed by our test statistics. First, utilizing the $t_{\mathrm{ADF} 2}$, we found that the null of nonstationarity is rejected in favor of reversion to a linear trend in three out of twenty-fivecountries are Malaysia, Antigua and Belize. Second, we found one country, South Africa where the null of nonstationarity is rejected by $t_{\mathrm{DFGLS} 2}$ but not by $t_{\mathrm{ADF} 2}$. Third, there are nine additional countries (Bahrain, Fiji, Saudi Arabia, Algeria, Gabon, Ghana, the Bahamas, Australia and Slovak Republic) for which the null is rejected in favor of nonlinear mean reversion to a trend either by $t_{\mathrm{NL} 21}$ and $t_{\mathrm{NL} 22}$ but not by $t_{\mathrm{ADF} 2}$ and $t_{\mathrm{DFGLS} 2}$. Thus, in comparison to other linear tests, the evidence suggests that the nonlinear tests provide more support for the productivity-bias hypothesis. Taken together, thirteen out of the seventy countries (i.e., 18.57\%) provide support for mean reversion to a trend. (Note 7)Overall, our results confirm that REERs in fifty-eight out of seventy countries (i.e., $82.86 \%$ ) are associated with either mean reversion or reversion to a trend.

\section{Summary and Conclusion}

This paper provides more up-to-date evidence on the validity of the PPP in LDCs. Following the recommendation of BOKZ (2008: 1061), the empirical study employs unit root tests which rely on both linear and nonlinear frameworks. We use three unique econometric tests to examine the stationarity or the mean reverting properties of real exchange rate. The first is the KSS test, a recently developed unit root test by KSS (2003), which pits the null of the unit root process (no adjustment towards PPP) against the alternative of a globally stationary ESTAR process (nonlinear adjustment towards PPP).

The second tests are the ADF and the DF-GLS. Both tests rely upon a linear framework. The null hypothesis in each case is non-stationarity (no adjustment towards PPP), and the alternative hypothesis is linear stationarity (linear adjustment towards PPP). Unlike some previous studies, these three tests are applied to monthly REERs instead of bilateral real exchange rates. Our use of REER allows us to focus on the international competitiveness of a country against all its trading partners and avoids bias concerning the choices of numeraire currency or choice of the base country in bilateral REER. The three tests are applied to monthly REERs for sixty-six countries over the 1980:1 through 2009:10 in some cases, culminating in 358 observations.

We find strong support for the stationarity of the real effective exchange rate in more than 65 percent of the cases. Hence, there is considerable evidence that PPP holds. Had we focused only on the empirical results of the linear tests, we would have missed the nonlinear features of real exchange rates in LDCs.Our results give credence to the fact that there is no "one-size-fits-all" model as a different procedure may be required to capture the individual nuances of different countries' data set. More importantly, our results also support the recommendation of BOKZ (2008: 1061) "that researchers should use both linear and nonlinear tests to determine the appropriate data generating process for real exchange rates." The findings of this paper are consistent with those of Arize, Malindretos and Nam (2010), Bahmani-Oskooee, Kutan and Zhou (2008), Kargbo (2006), Aggarwal and Simmons (2002), Arize et al. (2004), Salehizadeh and Taylor (1999) and Lui (1992) for various developing economies, who all find support for PPP.

Our results provide evidence on the mean reversion to a trend, which is a procedure commonly used for testing Harold-Balassa-Samuelson (HBS) effects or productivity bias hypothesis within the unit-root testing framework.Consistent with BOKZ (2008), we found minimal evidence (18.57\%) in supportof HBS effects in LDCs. Our results show that there is more evidence supporting nonlinear reversion to a trend than linear reversion to a trend. That is, the ADF (DF-GLS) test found linear reversion to a trend in two (four) countries, whereas the KSS test found evidence of nonlinear reversion to a trend in seven countries.

What policy conclusions can we draw from our empirical results? The lesson of this paper is that policymakers in developing countries should continue their PPP-oriented exchange rate policy reforms.Exchange rate policy must reflect the inflation differential between a country and its trading partners in order to maintain international competitiveness. The perfect is usually the enemy of the good, so for an LDCmaking policy, assuming that theeffectsofad evaluation on competitiveness willbe nonexistent in the long-term isfar betterthan inaction. Our results are encouraging because REER is found to revert to a constant mean in over 60 percent of the countries. This 
implies that relative prices play a vital role in determining the suitable levels of exchange rates in LDCs. In addition, our analysis also suggests that exchange rate policy actions aimed at stabilizing domestic economy can generate at best only uncertain results if the PPP, which has been a reliable guide for exchange rate determination, is ignored in the execution of exchange rate policy. Because of the wide variability shown by the results (linear and nonlinear adjustments), it is important that the approach to policy in each country is one that is coordinated so that it takes into account the existing economic, social and political environment in that country.

\section{References}

Aggarwal, R., \& Simmons, W. (2006). Economic integration among Caribbean countries: Evidence from purchasing power parity, 1980-2000. Journal of Policy Modeling, 28(3), 277-280. doi:10.1016/j.jpolmod.2005.08.004, http://dx.doi.org/10.1016/j.jpolmod.2005.08.004

Arize, A. C., Osang, T. \& Slottje, D. J. (2000).Exchange-rate Volatility and Foreign Trade: Evidence from Thirteen LDCs, Journal of Business and Economic Statistics, 18 (1), 10-12. doi:10.2307/1392132, http://dx.doi.org/10.2307/1392132

Arize, A.C., Malindretos J., and Grivoyannis, E.C. (2004).Purchasing Power Parity in developing Countries: Evidence from Conventional and Fractional Cointregration Tests, The International Journal of Banking and Finance, 2, 29-43.

Arize, A. C., Malindretos, J. \& Nam, K. (2010).Cointegration, Dynamic Structure, and the Validity of Purchasing Power Parity inAfrican Countries,International Review of Economics and Finance.19, 755-768. doi:10.1016/j.iref.2010.04.004, http://dx.doi.org/10.1016/j.iref.2010.04.004

Bahmani-Ooskooee, M. and Gelan, A. (2006).Testing the PPP in the STAR Framework: Evidence from Africa,Economics Bulletin, 6, 1-7.

Bahmani-Oskooee, M., Kutan, A. M., and Zhou, S. (2008). Do Real Exchange Rates Follow a Nonlinear Mean Reverting Process in Developing Countries? Southern Economic Journal, 74(4), 1049-1062.

Chortareas, G. and Kapetanios, G. (2004).The Yen Real Exchange Rate May Be Stationary after All: Evidence from Nonlinear Unit -Roots Tests.Oxford Bulletin of Economics and Statistics, 66, 113-131. doi:10.1046/j.0305-9049.2003.00080.x, http://dx.doi.org/10.1046/j.0305-9049.2003.00080.x

Commission of the European Communities (2009).Supporting Developing Countries in Coping with Crisis: Millennium Development Goals-Impact of the Financial Crisis on Developing Countries.Commission Staff Working Document, Brussels Sec (2009) 445/2.

Dornbusch, R. and Krugman, P. A. (1976). Flexible Exchange in the Short Run, Brookings Paperson Economic Activity, 537-575.

Elliot, G., Rothenberg, T.J., and Stock, J.H. (1996).Efficient Tests for an Autoregressive Unit Root.Econometricia, 64, 813-836. doi:10.2307/2171846, http://dx.doi.org/10.2307/2171846

Froot, K. A. and Rogoff, K. (1995).Perspectives on PPP and Long-run Exchange Rates.Handbook of International Economics,Vol. 3 (eds.) G. Grossman and K. Rogoff, North-Holland, New York, 1647-1688.

Gunst, R .F. and Mason R. L. (1980).Regression Analysis and its Application-A Data-Oriented Approach.Statistics Textbook \& Monograph.Mercel Dekker Inc. \#34.

Hausman, R., Pranizza U., and Rigobon, R.(2006).The Long-run Volatility Puzzle of the Real Exchange Rate,Journal of International Money and Finance, 23 (1), 93-124. doi:10.1016/j.jimonfin.2005.10.006, http://dx.doi.org/10.1016/j.jimonfin.2005.10.006

Hasan, Mohammad S. (2004).Univariate Time Series Behavior of the Real Exchange Rate: Evidence from Colonial India.Econometric Letters.84, 75-80. http://dx.doi.org/10.1016/j.econlet.2003.12.012

Hasan, Mohammed S. (2006). A Century of Purchasing Power parity: Evidence from Canada \& Australia. Applied Financial Economics, 16, 145-146. doi:10.1080/09603100500390091, http://dx.doi.org/10.1080/09603100500390091

International Monetary Fund, (2008, April).Globalization, Commodity Prices, \&Developing Countries.World Economic Outlook. Retrieved from http://www.imf.org/external/pubs/ft/weo/2008/01/pdf/c5.pdf

International Monetary Fund, (2010, February).International Financial Statistics, CD-ROM, International Monetary Fund, Washington DC.

Isard, P. (1977). How Far Can We Push the Law of One Price?American Economic Review, 67(5), 942-948

Kapetanios, G., Shin, Y., and Snell, A. (2003).Testing for a Unit Root in the Nonlinear STAR Framework.Journal of Econometrics, 112, 359-379. doi:10.1016/S0304-4076(02)00202-6, http://dx.doi.org/10.1016/S0304-4076(02)00202-6 
Kargbo, J. M. (2006). Purchasing Power Parity and Real Exchange Rate Behavior in Africa.Applied Financial Economics, 16, 169-183. doi:10.1080/09603100500389291, http://dx.doi.org/10.1080/09603100500389291

Kilian, L. and Taylor, M. P. (2003).Why It Is Difficult to Beat the Random Walk Forecastof Exchange Rates?Journal of International Economics 60, (1), 85-107. doi:10.1016/S0022-1996(02)00060-0, http://dx.doi.org/10.1016/S0022-1996(02)00060-0

Lothian, J. R., and Taylor, M.P. (2005).Real Exchange Rates Over the Past Two Centuries: How Important I the Harold-Balassa-Samuelson Effect? Mimeo, Fordham University, New York.

Liu, Peter (1992). Purchasing Power Parity in Latin America:Co-Intregation Analysis. WelwirtschaftlichesArchive, 128, 662-680. doi:10.1007/BF02707298, http://dx.doi.org/10.1007/BF02707298

McMillian, D.G. (2009). The Confusing Time Series of Behavior of Real Exchange Rates: Are Asymmetrics Important? Journal of International Financial Markets \& Money, 19, 692-711.

Ng, S. and P. Perron (1995).Unit Root Tests in ARMA Models with Data-Dependent Methods for the Selection of the Truncation Lag. Journal of the American Statistical Association, 90, 268-281. doi:10.2307/2291151, http://dx.doi.org/10.2307/2291151

Officer, L.H. (1976). Purchasing Power Parity Theory: A Review Article.IMP Staff Papers, 23, 1-60. doi:10.2307/3866665, http://dx.doi.org/10.2307/3866665

Rogoff, K. (1996). The Purchasing Power Parity Puzzle.Journal of Economic Literature, 34 (June), 647-667.

Salehizadeh, M. and Taylor, R. (1999).A Test of Purchasing Power Parity for Emerging Economies.Journal of International Financial Markets, Institutions and Money, 9, 183-93. doi:10.1016/S1042-4431(99)00006-2, http://dx.doi.org/10.1016/S1042-4431(99)00006-2

Samuelson, P. (1976). Is real world prices a tale told by the idiot of change? Review of Economics and Statistics, 58, 120-123. doi:10.2307/1936018, http://dx.doi.org/10.2307/1936018

Sarno, L. and Taylor, M. P. (2002).Purchasing Power Parity and the Real Exchange Rate.International Monetary Fund Staff Papers, 49, 65-105.

Sarno, L., Taylor, M. P., andChowdhury, I. (2004).Nonlinear Dynamics in Deviations from the Law of One-Price: A Broad-Based Empirical Study. Journal of International Money and Finance, 23, 1-25. doi:10.1016/j.jimonfin.2003.10.004, http://dx.doi.org/10.1016/j.jimonfin.2003.10.004

Taylor, A.M. (2001). Potential Pitfalls for the PPP Puzzle: Sampling\& Specification Biases in Mean-reversion Tests of the Law of One Price. Econometricia, 69, 473-498. doi:10.1111/1468-0262.00199, http://dx.doi.org/10.1111/1468-0262.00199

Taylor, A.M. (2002). A century of Purchasing Power Parity.Review of Economics and Statistics, 84, 139-150. doi:10.1162/003465302317331973, http://dx.doi.org/10.1162/003465302317331973

Taylor, M. P. (2004). Is Official Exchange Rate Intervention Effective?Economica, 71, 1-12. doi:10.1111/j.0013-0427.2004.00354.x, http://dx.doi.org/10.1111/j.0013-0427.2004.00354.x

Taylor, A. M. and Taylor, M. P. (2004).The Purchasing Power Parity Debate.Journal ofEconomic Perspectives, 18(4), 135- 138.

Taylor, M. P., Peel, D. A., and Sarno, L. (2001).Nonlinear Mean Reversion in Real Exchange Rates:Towards a Solutionto the Purchasing Power Parity Puzzles.International Economics Review, 42, 1015 - 1042. doi:10.1111/1468-2354.00144, http://dx.doi.org/10.1111/1468-2354.00144

World Bank.(1996).Trends in Developing Economies World Bank, Washington DC.

World Bank. (2005). Economic Growth in the 1990s: Learning from a Decade of Reform, Washington DC: Oxford University Press.

Yazgan, M. E. (2003). The Purchasing Power Parity for a high Inflation Country: A Reexamination of the case of Turkey.Applied Economic Letters, 10, 145-147. doi:10.1080/1350485022000041078, http://dx.doi.org/10.1080/1350485022000041078

\section{Notes}

Note 1 . In its relative version, it states that changes in the nominal exchange rate should be equal to the inflation differential between the domestic and foreign countries. For example, if the U.S. price level rises by $9 \%$ over the year while Ghana's price level rises by $18 \%$, then relative PPP predicts that the dollar will appreciate against the Ghana's cedis by $9 \%$. The appreciation against the Ghana's cedis cancels the differential in the inflation rates. Therefore, relative foreign and domestic purchasing powers of both currencies will remain unchanged. Alternatively, if U.S. price level rises by $9 \%$ and Ghana's price level rises by $8 \%$, the dollar will depreciate against the cedis by $1 \%$ to balance out. Accordingly, changes in nominal exchange rates outweigh changes in domestic prices relative to 
foreign prices in the long-run and real exchange rates (REER) exhibit reversion towards constant (mean) equilibrium rates.

Note 2. Or as Samuelson (1976: 123) points out "still, even if we can't measure something, econometrically, we may still have strong grounds for believing in it....". At least most economists share thought with respect to the PPP.

Note 3. A nonstationary REER suggests that shocks to REER series are permanent and therefore violates the PPP theory. It also means that arbitrage can take place and that market participants can buy goods at a lower price in one country and sell it at a higher price in another country.

Note 4. Changes in trade barriers, such as tariffs or quotas, are like real shocks that can create price differentials across countries. If these barriers prevent international movement of goods, price discrepancies could take a long time to correct.

Note 5. The argument behind the sample selection or survivorship bias is that long-span time series studies, which support PPP focus on real exchange rates between industrialized countries for which HBS effect is less observed (Froot and Rogoff, 1995). They suggest that caution is necessary when interpreting results from such studies because by failing to include LDCs, such studies are likely to suffer from sample selection bias. HBS have argued that deviation from PPP between rich and poor countries could be persistent due to differences in productivity. The higher productivity in the tradable sectors of the rich country increases the wages in both the tradable and the nontradeable sectors. For LDCs whose relative income has increased or decreased over a long period of time, it is likely that PPP will not hold because of cost-pressure trends in the nontradeable sector, whereas, in the industrialized economies, such cost-push pressure (arising from wages increases) on prices would have minor effects because of the relatively higher productivity of their nontradeable sector.

Note 6. For illustrative purposes, the real effective exchange rates can be calculated as in Arize, Osang and Slottje (2000a) as: reer $(j, t)=\operatorname{EXP}\left[-\ln P(j, t)+\ln E(j, \$, t)+\sum \mathrm{w}_{j i} \ln P(i, t)-\left[\sum w_{j i} \ln E(i, \$, t)\right]\right.$-where the exchange rate terms are in units of country $i$ (or $j$ ) currency per U.S. dollars in index form $(2000=1.0)$. P is the consumer price index of country $i$ (or $j$ ) in index form $(2000=1.0)$. For illustrative purposes, let Ghana be country $j$. $\mathrm{EXP}=$ exponent, $\ln =$ natural logarithm, $E(i, \$, t)=$ exchange-rate index of country $i$ at time $t$ and $E(j, \$, t)=$ exchange-rate index of Ghana at time $t$. An increase in the value of the index reflects depreciation, whereas a decline implies a real appreciation of the domestic currency.

Note7. The thirteen countries are a mixture of four countries in Asia (Bahrain, Fiji, Saudi Arabia and Malaysia); four in Africa (Algeria, Gabon, Ghana and South Africa); three in Latin America (Antigua, Belize and the Bahamas; and two in Europe (Australia and Slovak Republic).

Table 1. Basic Characteristics on Real Effective Exchange Rates

\begin{tabular}{|c|c|c|c|c|c|c|c|c|}
\hline \multirow[b]{2}{*}{ Country } & \multirow[b]{2}{*}{ Period } & \multicolumn{2}{|c|}{ 1980:1- 2005:8 } & \multicolumn{2}{|c|}{ 2005:9 - 2009:10 } & \multicolumn{3}{|c|}{ 1980:1 - 2009:10 } \\
\hline & & $\begin{array}{c}\text { CV } \\
\text { REER }\end{array}$ & Jarque-Bera & $\begin{array}{c}\text { CV } \\
\text { REER } \\
\end{array}$ & Jarque-Bera & $\begin{array}{c}\text { CV } \\
\text { REER }\end{array}$ & $\begin{array}{c}\text { CV } \\
\text { NEER } \\
\end{array}$ & $\begin{array}{l}\mathrm{CV} \\
\mathrm{RP} \\
\end{array}$ \\
\hline Asia: & & & & & & & & \\
\hline Bahrain & 1980:1-2009:10 & 0.2 & 31.25 & 0.07 & $2.19^{*}$ & 0.27 & 0.11 & 0.18 \\
\hline China & 1980:1-2009:10 & 0.46 & 88.55 & 0.07 & $2.95^{*}$ & 0.18 & 0.18 & 0.06 \\
\hline Fiji & 1980:1-2009:10 & 0.17 & 28.25 & 0.08 & $20.79 *$ & 0.45 & 0.56 & 0.19 \\
\hline Iran & 1980:1-2009:10 & 0.61 & 21.32 & 0.12 & $4.58 *$ & 0.71 & 1.37 & 0.95 \\
\hline Israel & 1980:1-2009:10 & 0.09 & 12.52 & 0.06 & $4.95^{*}$ & 0.09 & 3.11 & 3.19 \\
\hline Malaysia & 1980:1-2009:10 & 0.19 & 12.31 & 0.04 & $4.44 *$ & 0.2 & 0.16 & 0.05 \\
\hline Pakistan & 1980:1-2009:10 & 0.24 & 22.29 & 0.02 & $30.16^{*}$ & 0.3 & 0.51 & 0.26 \\
\hline Papua New Guinea & 1980:1-2009:10 & 0.17 & 14.68 & 0.07 & $108.03 *$ & 0.16 & 0.32 & 0.27 \\
\hline Philippines & 1980:1-2009:10 & 0.15 & 13.16 & 0.08 & $4.35^{*}$ & 0.16 & 0.67 & 0.5 \\
\hline Samoa & 1980:1-2009:10 & 0.14 & 3763.75 & 0.42 & $35.27^{*}$ & 0.12 & 0.26 & 0.15 \\
\hline Saudi Arabia & 1980:1-2009:10 & 0.24 & 35.34 & 0.12 & $37.65^{*}$ & 0.33 & 0.14 & 0.19 \\
\hline Singapore & 1980:1-2009:10 & 0.08 & 25.45 & 0.04 & $1.60^{*}$ & 0.07 & 0.12 & 0.11 \\
\hline $\begin{array}{l}\text { Solomon Islands } \\
\text { Africa: }\end{array}$ & 1980:1-2009:10 & 0.16 & 28.29 & 0.09 & $2.88^{*}$ & 0.18 & 0.7 & 0.53 \\
\hline Algeria & 1980:1-2009:10 & 0.46 & 33.4 & 0.04 & $10.51 *$ & 0.58 & 1.03 & 0.59 \\
\hline Burundi & 1980:1-2009:10 & 0.27 & 13.02 & 0.09 & $32.58 *$ & 0.29 & 0.47 & 0.31 \\
\hline Cameroon & 1980:1-2009:10 & 0.17 & 14.19 & 0.04 & $4.60^{*}$ & 0.17 & 0.19 & 0.19 \\
\hline Central African Rep & 1980:1-2009:10 & 0.21 & 24.64 & 0.06 & $3.01 *$ & 0.19 & 0.23 & 0.31 \\
\hline Congo & 1980:1-2009:10 & 0.54 & 14.44 & 0.11 & $116.38^{*}$ & 0.83 & 2.31 & 1.92 \\
\hline Cote d' Ivoire & 1980:1-2009:10 & 0.16 & 14.44 & 0.03 & $4.26^{*}$ & 0.15 & 0.28 & 0.28 \\
\hline Equatorial Guinea & 1985:1-2009:10 & 0.17 & 1.43 & 0.07 & $3.46^{*}$ & 0.18 & 0.93 & 0.21 \\
\hline Gabon & 1980:1-2009:10 & 0.31 & 39.43 & 0.04 & $4.85^{*}$ & 0.32 & 0.23 & 0.26 \\
\hline Gambia & 1980:1-2009:10 & 0.35 & 271.07 & 0.15 & $5.02 *$ & 0.29 & 0.5 & 0.24 \\
\hline
\end{tabular}




\begin{tabular}{|c|c|c|c|c|c|c|c|c|}
\hline Ghana & 1980:1-2009:10 & 0.54 & 18.6 & 0.04 & $16.76^{*}$ & 2 & 2.36 & 1.69 \\
\hline Malawi & 1980:1-2009:10 & 0.33 & 40.06 & 0.59 & $10.37^{*}$ & 0.25 & 0.91 & 0.81 \\
\hline Morocco & 1980:1-2009:10 & 0.09 & 27.65 & 0.02 & $10.64^{*}$ & 0.1 & 0.1 & 0.11 \\
\hline Nigeria & 1980:1-2009:10 & 0.54 & 12.29 & & 0.05 & $72.11^{*}$ & & 0.88 \\
\hline Sierra Leone & 1980:1-2009:10 & 0.4 & 60.06 & 0.36 & $62.38^{*}$ & 0.56 & 1.97 & 2.03 \\
\hline Ghana & 1980:1-2009:10 & 0.54 & 18.6 & 0.04 & $16.76^{*}$ & 2 & 2.36 & 1.69 \\
\hline Malawi & 1980:1-2009:10 & 0.33 & 40.06 & 0.59 & $10.37^{*}$ & 0.25 & 0.91 & 0.81 \\
\hline Morocco & 1980:1-2009:10 & 0.09 & 27.65 & 0.02 & $10.64 *$ & 0.1 & 0.1 & 0.11 \\
\hline Nigeria & 1980:1-2009:10 & 0.54 & 12.29 & & 0.05 & $72.11^{*}$ & & 0.88 \\
\hline Sierra Leone & 1980:1-2009:10 & 0.4 & 60.06 & 0.36 & $62.38^{*}$ & 0.56 & 1.97 & 2.03 \\
\hline South Africa & 1980:1-2009:10 & 0.21 & 55.08 & 0.09 & $1.11 *$ & 0.21 & 0.8 & 0.58 \\
\hline Togo & 1980:1-2009:10 & 0.19 & 10.33 & 0.03 & $38.22 *$ & 0.18 & 0.17 & 0.17 \\
\hline & & \multicolumn{2}{|c|}{ 1980:1- 2005:8 } & \multicolumn{2}{|c|}{ 2005:9-2009:10 } & \multicolumn{3}{|c|}{ 1980:1 - 2009:10 } \\
\hline Country & Period & $\begin{array}{c}\text { CV } \\
\text { REER }\end{array}$ & Jarque-Bera & $\begin{array}{c}\text { CV } \\
\text { REER }\end{array}$ & Jarque-Bera & $\begin{array}{c}\text { CV } \\
\text { REER }\end{array}$ & $\begin{array}{c}\text { CV } \\
\text { NEER }\end{array}$ & $\begin{array}{l}\mathrm{CV} \\
\mathrm{RP} \\
\end{array}$ \\
\hline Tunisia & 1980:1-2009:10 & 0.14 & 41.85 & 0.02 & $2.45^{*}$ & 0.18 & 0.3 & 0.11 \\
\hline Uganda & 1980:1-2009:10 & 0.44 & 16.63 & 0.14 & $11.20^{*}$ & 1.33 & 3.57 & 2.15 \\
\hline Zambia & 1980:1-2009:10 & 0.35 & 6113.65 & 0.09 & $0.14 *$ & 0.31 & 1.71 & 1.57 \\
\hline \multicolumn{9}{|l|}{ Latin America: } \\
\hline Antigua & 1980:1-2009:10 & 0.07 & 41 & 0.02 & $1.05^{*}$ & 0.08 & 0.07 & 0.09 \\
\hline Bahamas & 1980:1-2009:10 & 0.05 & 6.07 & 0.04 & $0.93 *$ & 0.05 & 0.1 & 0.08 \\
\hline Belize & 1980:1-2009:10 & 0.07 & 76.82 & 0.03 & $1.34 *$ & 0.08 & 0.22 & 0.26 \\
\hline Bolivia & 1980:1-2009:10 & 0.81 & 91511.34 & 0.11 & $6.95 *$ & 0.8 & 2.74 & 2.71 \\
\hline Chile & 1980:1-2009:10 & 0.2 & 37.48 & 0.04 & $5.06^{*}$ & 0.26 & 0.27 & 0.3 \\
\hline Colombia & 1980:1-2009:10 & 0.22 & 21.43 & 0.08 & $0.50 *$ & 0.24 & 0.74 & 0.51 \\
\hline Costa Rica & 1980:1-2009:10 & 0.12 & 2217.83 & 0.05 & $4.83 *$ & 0.12 & 0.82 & 0.64 \\
\hline Dominica & 1980:1-2009:10 & 0.07 & 33.46 & 0.02 & $2.35 *$ & 0.07 & 0.2 & 0.22 \\
\hline Dominican Rep. & 1980:1-2009:10 & 0.19 & 7.49 & 0.15 & $2923.36^{*}$ & 0.19 & 0.85 & 0.67 \\
\hline Grenada & 1980:1-2009:10 & 0.07 & 59.86 & 0.21 & $843.75^{*}$ & 0.07 & 0.27 & 0.29 \\
\hline Guyana & 1980:1-2009:10 & 0.54 & 40.88 & 0.26 & $309.75^{*}$ & 0.97 & 1.29 & 0.65 \\
\hline Netherlands Antilles & 1980:1-2009:10 & 0.11 & 21.99 & 0.11 & $9.94 *$ & 0.11 & 0.49 & 0.5 \\
\hline Nicaragua & 1980:1-2009:10 & 1.33 & 722.04 & 0.15 & $2803.69^{*}$ & 5.43 & 1.9 & 2.08 \\
\hline Paraguay & 1980:1-2009:10 & 0.33 & 131.68 & 0.33 & $68.63 *$ & 0.27 & 0.76 & 0.75 \\
\hline St. Kitts \& Nevis & 1980:1-2009:10 & 0.06 & 17.61 & 0.03 & $1.79 *$ & 0.06 & 0.06 & 0.08 \\
\hline St. Lucia & 1980:1-2009:10 & 0.06 & 5.63 & 0.26 & $329.94 *$ & 0.05 & 0.14 & 0.12 \\
\hline St. Vincent \&Grens & 1980:1-2009:10 & 0.05 & 20.44 & 0.04 & $8.55^{*}$ & 0.05 & 0.17 & 0.17 \\
\hline Tobago \& Trinidad & 1980:1-2009:10 & 0.14 & 90.85 & 0.07 & $6.10^{*}$ & 0.16 & 0.25 & 0.16 \\
\hline Uruguay & 1980:1-2009:10 & 0.26 & 77.97 & 0.07 & $5.58 *$ & 0.2 & 0.51 & 0.46 \\
\hline Venezuela & 1980:1-2009:10 & 0.35 & 0.44 & 0.33 & $34.99 *$ & 0.3 & 1.39 & 1.17 \\
\hline \multicolumn{9}{|l|}{ Europe: } \\
\hline Armenia & 1993:11-2009:10 & 0.49 & 1000.98 & 0.13 & $2.84^{*}$ & 0.26 & 0.35 & 0.34 \\
\hline Australia & 1980:1-2009:10 & 0.12 & 13.42 & 0.07 & $4.09 *$ & 0.12 & 0.11 & 0.08 \\
\hline Bulgaria & 1992:1-2009:10 & 0.32 & 155.65 & 0.08 & $4.80 *$ & 0.28 & 1.46 & 1.58 \\
\hline Croatia & 1992:1-2009:10 & 0.16 & 783.42 & 0.03 & $2.92 *$ & 0.11 & 2.68 & 3.15 \\
\hline Cyprus & 1980:1-2009:10 & 0.06 & 17.36 & 0.04 & $118.12 *$ & 0.07 & 0.16 & 0.15 \\
\hline Czech Republic & 1990:1-2009:10 & 0.22 & 18.9 & 0.08 & $4.61 *$ & 0.26 & 0.16 & 0.22 \\
\hline Greece & 1980:1-2009:10 & 0.08 & 9.66 & 0.02 & $4.04 *$ & 0.08 & 0.71 & 0.75 \\
\hline Hungary & 1980:1-2009:10 & 0.19 & 8.10 & 0.07 & $1.65^{*}$ & 0.25 & 0.61 & 0.73 \\
\hline Iceland & 1980:1-2009:10 & 0.13 & 111.5 & 0.21 & $7.31 *$ & 0.16 & 1.23 & 0.93 \\
\hline Malta & 1980:1-2009:10 & 0.08 & 19.09 & 0.04 & $2.00^{*}$ & 0.08 & 0.06 & 0.08 \\
\hline \multirow[t]{2}{*}{ Moldova } & 1980:1-2009:10 & 0.12 & 0.14 & 0.08 & $1.02 *$ & 0.17 & 0.26 & 0.28 \\
\hline & & \multicolumn{2}{|c|}{ 1980:1- 2005:8 } & \multicolumn{2}{|c|}{ 2005:9-2009:10 } & \multicolumn{3}{|c|}{ 1980:1 - 2009:10 } \\
\hline Country & Period & $\begin{array}{c}\text { CV } \\
\text { REER }\end{array}$ & Jarque-Bera & $\begin{array}{c}\text { CV } \\
\text { REER }\end{array}$ & Jarque-Bera & $\begin{array}{c}\text { CV } \\
\text { REER }\end{array}$ & $\begin{array}{c}\text { CV } \\
\text { NEER }\end{array}$ & $\begin{array}{l}\text { CV } \\
\text { RP }\end{array}$ \\
\hline New Zealand & 1993:11-2009:10 & 0.1 & 5.5 & 0.08 & $9.63 *$ & 0.1 & 0.15 & 0.16 \\
\hline Norway & $1980: 1-2009: 10$ & 0.04 & 0.31 & 0.04 & $7.45^{*}$ & 0.2 & 0.08 & 0.22 \\
\hline Poland & $1980: 1-2009: 10$ & 0.72 & 11.94 & 0.12 & $583.62 *$ & 1.18 & 1.71 & 1.74 \\
\hline Romania & $1980: 1-2009: 10$ & 0.37 & 326.45 & 0.05 & $1.56^{*}$ & 0.29 & 1.27 & 1.22 \\
\hline Russia & $1993: 11-2009: 10$ & 0.19 & 13.94 & 0.06 & $2.06^{*}$ & 0.21 & 0.75 & 0.9 \\
\hline Slovak Republic & 1990:1-2009:10 & 0.16 & 5.58 & 0.1 & $3.08 *$ & 0.29 & 0.12 & 0.25 \\
\hline
\end{tabular}

Notes: The Jarque-Bera statistic is distributed as Chi-squares with 2 degrees of freedom. The null hypothesis is normality and an asterisk implies not significant at the $5 \%$ level (the critical value is 5.99). The F test examines the equality of variances between the two sample periods and an asterisk imply significant as the $5 \%$ level. $\mathrm{CV}$ is the coefficient of variation. 
Table 2. Unit Root Results for Asian LDCs

\begin{tabular}{|c|c|c|c|c|c|c|c|c|c|}
\hline \multirow[t]{2}{*}{ Country } & \multirow[t]{2}{*}{ Sample Period } & \multirow[b]{2}{*}{$t_{\mathrm{ADF1}}$} & \multirow[b]{2}{*}{$t_{\text {DFGLS1 }}$} & \multicolumn{2}{|c|}{ Demeaned Data } & \multirow[b]{2}{*}{$t_{\mathrm{ADF} 2}$} & \multirow[b]{2}{*}{$t_{\text {DFGLS2 }}$} & \multicolumn{2}{|c|}{ Detrended Data } \\
\hline & & & & $t_{\mathrm{NL11}}$ & $t_{\mathrm{NL12}}$ & & & $t_{\mathrm{NL21}}$ & $t_{\mathrm{NL22}}$ \\
\hline Bahrain & 1980:1-2009:8 & -0.86 & 0.42 & -0.02 & -1.51 & -2.26 & -2.17 & -2.20 & $-3.18^{*}$ \\
\hline Fiji & 1980:1-2009:8 & -1.59 & -0.14 & -0.69 & -0.44 & -2.48 & -2.44 & $-3.42 *$ & -2.84 \\
\hline China & 1980:1-2009:10 & -2.11 & -0.03 & -2.12 & $-2.66^{*}$ & -1.70 & -1.02 & -2.12 & -2.19 \\
\hline Iran & 1980:1-2009:8 & -1.66 & -1.01 & -1.52 & -1.68 & -1.41 & -1.53 & -1.40 & -1.54 \\
\hline Israel & 1980:1-2009:8 & -2.02 & -0.67 & $-6.33 *$ & -1.91 & -1.99 & -1.49 & $-5.61 *$ & -1.75 \\
\hline Pakistan & 1980:1-2009:8 & -1.91 & 0.59 & -0.95 & -1.96 & -1.47 & -1.65 & -2.07 & -1.07 \\
\hline Papua New Guinea & 1980:1-2009:10 & -1.75 & -0.78 & -2.52 & -1.58 & -2.00 & -1.95 & -2.66 & -1.45 \\
\hline Philippines & 1980:1-2009:8 & -2.22 & -0.83 & -1.86 & -2.02 & -2.15 & -1.62 & -2.05 & -2.45 \\
\hline Samoa & 1980:1-2009:8 & -1.17 & -0.98 & $-16.35^{*}$ & $-3.45^{*}$ & -1.22 & -0.90 & $-16.35 *$ & $-3.46^{*}$ \\
\hline Saudi Arabia & 1980:1-2009:8 & -1.55 & 0.38 & -1.66 & -0.83 & -1.40 & -1.31 & $-7.60 *$ & $-4.09 *$ \\
\hline Singapore & 1980:1-2009:8 & $-2.88^{*}$ & $-2.95^{*}$ & -1.12 & $-2.93 *$ & -2.88 & $-2.98 *$ & -1.11 & -2.93 \\
\hline \multicolumn{2}{|c|}{ Critical Values at $10 \%$ level } & -2.57 & -1.62 & -2.66 & -2.66 & -3.12 & -2.59 & -3.13 & -3.13 \\
\hline
\end{tabular}

Notes: $t_{\mathrm{ADF} 1}$ and $t_{\mathrm{ADF} 2}$ are the conventional ADF test statistic for the null hypothesis of nonstationarity and the null of trend nonstationarity, respectively. ADF test statics refer to the conventional ADF test. The DFGLS test statistics are Elliot, Rothenberg and Stock (1996) test statistic. $t_{\mathrm{NL} 11}$ and $t_{\mathrm{NL} 12}$ are the KSS test statistics for the de-meaned data using the models without and with augmentations, respectively. $t_{\mathrm{NL} 21}$ and $t_{\mathrm{NL} 22}$ are the KSS test statistics for the detrended data using the models without and with augmentations, respectively. The $10 \%$ asymptotic critical value for $t_{\mathrm{ADF} 1}$ is -2.57 , respectively and that for $t_{\mathrm{ADF} 2}$ is -3.12 . The $10 \%$ asymptotic critical values for $t_{\mathrm{NL} 11}$ and $t_{\mathrm{NL} 12}$ are -2.66 , respectively, and those for $t_{\mathrm{NL} 21}$ and $t_{\mathrm{NL} 22}$, it is -3.13 , respectively. These critical values are taken from Kapetanios, Shin and Snell (2003). Also, $t_{\mathrm{DFGLS} 1}$ was obtained using E-Views 6 . The $10 \%$ critical values are -1.62 respectively and those for $t_{\mathrm{DFGLS} 2}$ are $\quad-2.59$ respectively.

*denote rejection of the null hypothesis at $10 \%$ significance levels, respectively.

Table 3. Unit Root Results for African LDCs

\begin{tabular}{|c|c|c|c|c|c|c|c|c|c|}
\hline \multirow[t]{2}{*}{ Country } & \multirow[t]{2}{*}{ Sample Period } & \multirow[b]{2}{*}{$t_{\mathrm{ADF} 1}$} & \multirow[b]{2}{*}{$t_{\text {DFGLS1 }}$} & \multicolumn{2}{|c|}{ Demeaned Data } & \multirow[b]{2}{*}{$t_{\mathrm{ADF} 2}$} & \multirow[b]{2}{*}{$t_{\text {DFGLS2 }}$} & \multicolumn{2}{|c|}{ Detrended Data } \\
\hline & & & & $t_{\mathrm{NL11}}$ & $t_{\mathrm{NL12}}$ & & & $t_{\mathrm{NL21}}$ & $t_{\mathrm{NL22}}$ \\
\hline Algeria & 1980:1-2009:8 & -2.14 & 0.99 & -0.61 & -0.58 & -2.15 & -1.41 & -2.72 & $-3.53 *$ \\
\hline Burundi & 1980:1-2009:8 & -1.21 & -0.47 & $-3.63 *$ & -2.02 & -2.64 & -2.07 & $-10.77 *$ & $-6.24 *$ \\
\hline Cameroon & 1980:1-2009:8 & -2.11 & -1.08 & $-3.44^{*}$ & -1.31 & -2.54 & -1.80 & $-3.95^{*}$ & -2.51 \\
\hline Central African Rep & 1980:1-2009:8 & -1.52 & -0.52 & $-4.83 *$ & $-2.68 *$ & -1.94 & -1.33 & $-4.89 *$ & -2.36 \\
\hline Congo & 1980:1-2009:8 & -1.62 & -0.24 & $-3.16^{*}$ & -1.60 & -3.03 & $-3.18^{*}$ & $-5.39 *$ & -4.21 \\
\hline Cote d' Ivoire & 1980:1-2009:8 & $-2.79 *$ & -1.00 & $-3.28 *$ & $-2.97 *$ & -2.75 & -1.86 & $-3.31 *$ & -3.00 \\
\hline Equatorial Guinea & 1985:1-2009:10 & $-3.52 *$ & -0.14 & -1.44 & -1.36 & $-3.26^{*}$ & -0.97 & -2.74 & -2.74 \\
\hline Gabon & 1980:1-2009:8 & -1.04 & 0.42 & -2.51 & -1.34 & -2.28 & -1.29 & $-5.07 *$ & -2.25 \\
\hline Gambia & 1980:1-2009:8 & -1.46 & -1.08 & -1.26 & -1.86 & -1.89 & 2.42 & -1.39 & -2.27 \\
\hline Ghana & 1980:1-2009:8 & -1.57 & 0.21 & -1.09 & -1.73 & -2.44 & -2.44 & -1.93 & $-3.29 *$ \\
\hline Lesotho & 1980:1-2009:8 & -2.29 & -1.99 & $-10.74 *$ & $-6.55^{*}$ & -2.30 & -2.10 & $-11.20 *$ & 7.03 \\
\hline Malawi & $1980: 1-2009: 8$ & -2.11 & -1.11 & $-15.19 *$ & $-4.92 *$ & $-3.83 *$ & $-3.21 *$ & $-13.16^{*}$ & -2.84 \\
\hline Morocco & 1980:1-2009:8 & -2.26 & -0.40 & -2.57 & -1.77 & -1.89 & -0.77 & -2.68 & -1.85 \\
\hline Nigeria & 1980:1-2009:8 & -2.13 & -0.89 & $-2.90 *$ & -2.38 & -2.09 & -1.73 & $-4.00 *$ & $-3.29 *$ \\
\hline Sierra Leone & 1980:1-2009:8 & -2.15 & -0.97 & $-11.86^{*}$ & $-5.41 *$ & -2.92 & $-2.86^{*}$ & $-11.44^{*}$ & $-4.82 *$ \\
\hline South Africa & 1980:1-2009:8 & -2.02 & -0.76 & -2.35 & -2.33 & -2.83 & $-2.93 *$ & -2.89 & -2.73 \\
\hline Togo & 1980:1-2009:8 & -1.71 & 0.47 & $-4.48 *$ & -1.98 & -2.55 & -2.02 & $-4.63 *$ & -2.04 \\
\hline Tunisia & 1980:1-2009:8 & -1.41 & -0.46 & -1.11 & -1.43 & -2.20 & -1.27 & -1.58 & -2.13 \\
\hline Uganda & 1980:1-2009:8 & -2.19 & 0.26 & $-4.42 *$ & $-3.97 *$ & $-3.57^{*}$ & -2.08 & $-8.39 *$ & $-7.60 *$ \\
\hline Zambia & 1980:1-2009:8 & $-2.96^{*}$ & $-2.09 *$ & $-13.99 *$ & $-11.83 *$ & $-3.48^{*}$ & -2.19 & -14.47 & $-12.41 *$ \\
\hline $\begin{array}{l}\text { Critical Values at } \\
-3.13\end{array}$ & level & \multicolumn{2}{|c|}{-2.57} & -2.66 & -2.66 & -3.12 & -2.59 & \multicolumn{2}{|c|}{-3.13} \\
\hline
\end{tabular}

See notes to Table 1 . 
Table 4. Unit Root Results for Latin American LDCs

\begin{tabular}{|c|c|c|c|c|c|c|c|c|c|}
\hline \multirow[t]{2}{*}{ Country } & \multirow[t]{2}{*}{ Sample Period } & \multirow[b]{2}{*}{$t_{\mathrm{ADF} 1}$} & \multirow[b]{2}{*}{$t_{\text {DFGLS1 }}$} & \multirow{2}{*}{$\begin{array}{l}\text { Demeaned Data } \\
t_{\mathrm{NL11}} \\
\end{array}$} & \multirow[b]{2}{*}{$t_{\mathrm{NL12}}$} & \multirow[b]{2}{*}{$t_{\mathrm{ADF} 2}$} & \multirow[b]{2}{*}{$t_{\mathrm{DFGLS} 2}$} & \multicolumn{2}{|c|}{ Detrended Data } \\
\hline & & & & & & & & $t_{\mathrm{NL21}}$ & $t_{\mathrm{NL} 22}$ \\
\hline Antigua & 1980:1-2009:8 & -0.62 & -1.47 & -0.59 & -0.62 & $-3.36^{*}$ & -1.50 & -2.52 & -2.54 \\
\hline Bahamas & 1980:1-2009:8 & -0.86 & -0.77 & -0.02 & -1.51 & -2.26 & -1.33 & -2.20 & $-3.18 *$ \\
\hline Belize & 1980:1-2009:8 & -1.52 & -1.02 & -2.17 & -1.07 & $-3.13 *$ & -1.29 & $-8.16^{*}$ & -1.14 \\
\hline Bolivia & 1980:1-2009:10 & -1.97 & -0.82 & $-7.76^{*}$ & $-7.76^{*}$ & -2.03 & $-2.06^{*}$ & $-10.12 *$ & $-8.90^{*}$ \\
\hline Chile & 1980:1-2009:8 & $-3.08^{*}$ & -0.77 & -1.05 & -2.56 & -2.57 & -1.74 & -1.33 & -2.29 \\
\hline Colombia & 1980:1-2009:8 & -1.70 & -1.05 & -2.65 & -2.41 & -1.38 & -1.66 & -2.56 & -2.31 \\
\hline Costa Rica & 1980:1-2009:8 & $-4.17 *$ & -1.50 & $-4.03^{*}$ & $-3.60^{*}$ & $-4.14 *$ & $-3.10^{*}$ & $-4.06^{*}$ & $-3.57^{*}$ \\
\hline Dominica & 1980:1-2009:8 & -2.13 & -1.01 & -2.24 & -2.28 & -2.43 & -1.21 & -2.30 & -2.80 \\
\hline Dominican Republic & 1980:1-2009:8 & $-2.79^{*}$ & -0.84 & $-13.73 *$ & $-11.03 *$ & -2.71 & -1.46 & $-13.99 *$ & $-11.34 *$ \\
\hline Grenada & $1980: 1-2009: 8$ & $-2.68 *$ & -0.79 & $-18.55^{*}$ & $-5.59 *$ & $-3.14 *$ & -1.25 & $-18.54^{*}$ & $-5.55^{*}$ \\
\hline Guyana & 1980:1-2009:8 & -1.86 & -0.66 & $-3.04 *$ & -1.86 & -1.90 & -1.79 & $-6.15^{*}$ & $-3.13 *$ \\
\hline Netherlands Antilles & 1980:1-2009:10 & -1.82 & -0.92 & -0.01 & -0.01 & -1.53 & -0.89 & -0.04 & -0.02 \\
\hline Nicaragua & 1980:1-2009:8 & $-3.44 *$ & $-1.85^{*}$ & -2.26 & -2.39 & $-3.44 *$ & $-2.65^{*}$ & -2.27 & -2.39 \\
\hline Paraguay & 1980:1-2009:8 & $-2.76^{*}$ & -1.04 & $-8.21 *$ & $-3.64 *$ & -2.58 & -1.90 & $-8.21 *$ & $-3.72 *$ \\
\hline St. Kitts and Nevis & 1980:1-2009:8 & -1.99 & $-2.05^{*}$ & -2.65 & $-3.37^{*}$ & -2.00 & -2.11 & -2.64 & $-3.36^{*}$ \\
\hline St. Lucia & 1980:1-2009:8 & $-3.16^{*}$ & -0.44 & $-8.26^{*}$ & $-3.24 *$ & $-3.34 *$ & -1.84 & $-8.27 *$ & $-3.29 *$ \\
\hline St. Vincent and Grens & 1980:1-2009:8 & $-2.73 *$ & -1.13 & $-3.71^{*}$ & $-3.51 *$ & -2.87 & -1.80 & $-3.88^{*}$ & $-3.47 *$ \\
\hline Tobago \& Trinidad & 1980:1-2009:8 & -1.68 & $-1.77 *$ & -1.00 & -1.23 & -1.69 & -2.12 & -0.99 & -1.27 \\
\hline Uruguay & 1980:1-2009:8 & -1.80 & -1.28 & $-8.06^{*}$ & $-4.41 *$ & -2.56 & -1.34 & $-8.19^{*}$ & -2.50 \\
\hline Venezuela & 1980:1-2009:8 & -1.26 & -0.95 & $-12.56^{*}$ & $-4.39 *$ & -1.53 & -0.93 & $-12.10^{*}$ & $-4.06^{*}$ \\
\hline \multicolumn{2}{|c|}{ Critical Values at $10 \%$ level } & & \multicolumn{2}{|r|}{-2.57} & -1.62 & \multirow[t]{2}{*}{-2.66} & & & \\
\hline-2.66 & -3.12 & & -3.1 & -3.13 & & & & & \\
\hline
\end{tabular}

See notes to Table 1.

Table 5. Unit Root Results for European LDCs

\begin{tabular}{|c|c|c|c|c|c|c|c|c|c|}
\hline \multirow[t]{2}{*}{ Country } & \multirow[t]{2}{*}{ Sample Period } & \multirow[b]{2}{*}{$t_{\mathrm{ADF} 1}$} & \multirow[b]{2}{*}{$t_{\text {DFGLS1 }}$} & \multicolumn{2}{|c|}{ Demeaned Data } & \multirow[b]{2}{*}{$t_{\mathrm{ADF} 2}$} & \multirow[b]{2}{*}{$t_{\mathrm{DFGLS} 2}$} & \multicolumn{2}{|c|}{ Detrended Data } \\
\hline & & & & $t_{\mathrm{NL11}}$ & $t_{\mathrm{NL12}}$ & & & $t_{\mathrm{NL21}}$ & $t_{\mathrm{NL22}}$ \\
\hline Australia & 1980:1-2009:10 & -2.08 & -1.53 & -2.04 & -2.60 & -1.97 & -1.83 & -2.99 & $-3.85^{*}$ \\
\hline Armenia & 1993:11-2009:10 & -1.16 & -0.29 & $-4.56^{*}$ & -1.13 & -1.16 & -1.59 & $-4.62 *$ & -1.54 \\
\hline Bulgaria & $1992: 1-2009: 10$ & -2.30 & $-1.96^{*}$ & $-5.84 *$ & $-4.59^{*}$ & $-4.40^{*}$ & -1.52 & $-5.54^{*}$ & $-4.54 *$ \\
\hline Croatia & $1992: 1-2009: 10$ & -0.59 & -1.16 & $-13.22 *$ & -0.27 & -2.34 & $-3.18^{*}$ & $-12.47^{*}$ & -1.46 \\
\hline Cyprus & 1980:1-2009:8 & -1.76 & $-2.54 *$ & $-5.41 *$ & $-4.35^{*}$ & -1.85 & -1.43 & $-5.23 *$ & $-4.40 *$ \\
\hline Czech Republic & 1990:1-2009:10 & -1.44 & -0.41 & $-5.01 *$ & -0.47 & -2.70 & $-4.08^{*}$ & $-4.08^{*}$ & -3.01 \\
\hline Greece & $1980: 1-2009: 8$ & $-3.24 *$ & -0.43 & -2.13 & $-2.88^{*}$ & $-3.22 *$ & -1.23 & -2.36 & $-3.36^{*}$ \\
\hline Hungry & 1980:1-2009:10 & -0.56 & -0.70 & $-3.09 *$ & -1.40 & -2.48 & -2.10 & $-4.22 *$ & $-4.10 *$ \\
\hline Iceland & 1980:1-2009:10 & $-2.69^{*}$ & -0.17 & $-2.68^{*}$ & $-3.70^{*}$ & $-3.14^{*}$ & -2.12 & -2.77 & $-4.02 *$ \\
\hline Malta & 1980:1-2009:8 & -1.29 & -0.53 & -1.66 & $-2.70^{*}$ & -1.05 & -1.47 & -1.62 & -2.05 \\
\hline Moldova & 1993:11-2009:10 & -0.31 & $-1.82 *$ & -1.20 & -1.82 & -1.95 & -0.80 & $-3.54 *$ & $-3.60 *$ \\
\hline New Zealand & 1980:1-2009:10 & $-2.85^{*}$ & $-2.17 *$ & $-2.82 *$ & $-3.78^{*}$ & $-3.32 *$ & $-3.32 *$ & -2.52 & $-3.34 *$ \\
\hline Norway & 1980:1-2009:10 & -2.09 & -0.47 & $-3.47 *$ & $-3.49^{*}$ & -2.24 & -2.04 & $-3.33^{*}$ & $-3.17 *$ \\
\hline Poland & 1980:1-2009:10 & -2.56 & -1.39 & $-2.66^{*}$ & -2.20 & -2.48 & -2.15 & $-4.16^{*}$ & -2.94 \\
\hline Romania & 1980:1-2009:10 & -1.64 & -1.57 & -2.23 & -2.58 & -1.55 & -1.59 & -2.32 & -2.90 \\
\hline Russia & 1993:11-2009:10 & -1.75 & -0.56 & -1.81 & -2.65 & -2.30 & -2.41 & -1.61 & -2.30 \\
\hline Slovak Republic & 1990:1-2009:10 & -0.86 & -0.58 & -1.13 & -0.58 & -1.83 & -1.26 & $-3.33 *$ & $-3.35^{*}$ \\
\hline \multicolumn{2}{|c|}{ Critical Values at $10 \%$ level } & -2.57 & -1.62 & -2.66 & -2.66 & -3.12 & -2.59 & -3.13 & -3.13 \\
\hline
\end{tabular}

See notes to Table 1 